\title{
Assessment of Medical Waste Management at Cape Coast Teaching Hospital-Ghana
}

\author{
Isaac Tettey Adjokatse ${ }^{1} \quad$ Dr. Saviour Victor Kwabla Adjibolosoo ${ }^{2 *} \quad$ Licarion Kuwedomo Miine $^{3}$ \\ 1.Mfantsipim School, Science Department, Physics Unit, Cape Coast \\ 2.Presbyterian Women's College of Education, Aburi \\ 3.Mfantsipim School, Social Science Department, Cape Coast
}

The research is financed by the authors.

\begin{abstract}
Despite the public health and environmental consequences associated with medical waste, much attention has not been given to its management in health care centres in developing countries. This study assessed medical waste generation and management practices in the Cape Coast Teaching Hospital in Ghana. The study employed mixed methods. Quantitative and qualitative data were collected from seventy four (74) hospital employees using structured questionnaire, interview and observation. Quantitative data was analyzed using descriptive and t-test statistics at $\mathrm{p}<0.05$. Qualitative data was analyzed using thematic content analysis procedure. The study found that the Cape Coast Teaching Hospital generates an average daily medical waste of $35.12 \mathrm{~kg}(\mathrm{mean}=278.71, \mathrm{SD}=$ $20.263 ; \mathrm{t}=36.39, \mathrm{p}<0.05$ and medical waste per patient per day was $0.1291 \mathrm{~kg}$. Waste segregation was practiced using coloured bags $(20.3 \%)$, metal dust bins (36.5\%) and boxes (43.2\%). The hospital has no written policy guidelines for handling medical waste. The poor management practices of medical waste generated in the Teaching Hospital is a situation-driven as it was not clearly backed by any well-designed policy framework. This raises many questions about the human health and environmental implications and level of attention the Ministry of Local Government and Rural Development (MLGRD) and Ministry of Health (MOH) give to medical waste management practices in the Hospital. There is the need for a sustainable medical waste management system at the Cape Coast Teaching Hospital to avoid its negative impact on human health and the environment.
\end{abstract}

Keywords: Medical Waste, Medical Waste Management, Cape Coast Teaching Hospital, Central Region, Ghana. DOI: $10.7176 / \mathrm{JEES} / 11-10-02$

Publication date:October $31^{\text {st }} 2021$

\section{Introduction}

Hospital waste is any waste which is generated in the diagnosis, treatment or immunization of human beings or animals or in research in a hospital. Hospital waste is a special type of waste produced in small quantities carrying a high potential of infection and injury. Worldwide, the emphasis on special handling of medical waste as compared to other waste types has a long history. Various writers interested in medical waste have attempted to explain the phenomena while others have suggested various management practices. Even though there exists literature on the management of waste, it is still a well-known problem in most developing and developed countries.

In Ghana, proper medical waste disposal is the core responsibility of the person or institution that generates it with the assistance of stakeholders in waste management (Ministry of Health, 2006). Furthermore, hospitals are responsible for the waste that they produced by ensuring that waste is segregated and safely handled, kept as well as treated. Waste according to Ministry of Health $(\mathrm{MOH})$ should be safely disposed and that management of the waste must receive help from the relevant stakeholder bodies (Ministry of Health, 2006). The negative effects that accompany medical waste and its management have attracted a global attention. For example in Rio de Janerio in June 1992 world leaders met to adopt the Agenda 21 of the United Nations Conference on Environment and Development (UNCED). At the conference it was recognized that, uncovered medical waste is one of the greatest threat to the world today in their fight against environmental degradation. Based on this Cheng et al. (2009) identified that even though medical waste constituted a small fraction of total waste in a community, its management is seen as a very important issue worldwide. The increase in medical waste in these countries is largely because of a growth in population which has resulted in an increase in the demand for healthcare facilities (Mbongwe et al., 2008). Ramokate (2007) also reported that in under developed countries, where there is the high rate of HIV/AIDS cases, this leads to high hospital admissions hence an increase in the amount of waste generated by these facilities. However poor and improper disposal techniques employed during the management of medical waste has also compounded this problem.

In Ghana, beginning the year 2000, proper sanitary landfills were constructed all over the country to enhance medical waste residuals and ashes among other wastes are properly disposed off (Jamu et al., 2009). Usually, safe disposal of medical waste involves segregation, collection and storage, treatment, transport and safe disposal (World Health Organisation, 2008). The processes by which these waste are collected, stored and treated differ from facility to facility and from country to country. In the developed world the most common way of treating waste is through incineration, disinfection and sterilization. However the same cannot be said of developing 
countries where incineration is the most common method of treating waste and sharp objects. Though some health facilities use the effluent treatment system in treating chemical waste it is sometimes not efficient and uncertain. This has made some pharmaceutical wastes (including expired medicine) being left unattended to.

For most health staff, sharps such as needles are of major concern to the community. In most of the developing countries in the world, money is made from the sale of used sharps and plastics which poses a danger to human life. Hence, there is a probability that the unlawful reuse of contaminated sharps have the ability to pose threat to the entire community (Mujeeb et al., 2003). According to the World Health Organisation (2011), care must be taken when dealing with medical waste management which in this case is the core mandate of hospitals management. For the waste managers to reduce the risk associated with medical waste, it is argued that the waste be segregated, stored and later on destroyed.

In Ghana for instance, various methods have been adopted for waste disposal; some of these methods include the burial of the waste in pit and the careless dumping of the waste in land fill sites, other health facilities adopt the treatment of the waste with chemicals. These unapproved ways of discarding waste have proved extremely unhygienic and a major source of environmental pollution. During the raining season the stench that comes from buried placentas, and limbs are unbearable and awful within most healthcare facilities. Also at landfill sites, scavengers collect medical wastes such as syringes, which are sold for use as hair rollers (Kwawukume, 2005).

According to the WHO 1992 the greatest and immediate threat that poor handling of waste pose to health workers is the transmission of infectious disease (World Health Organization, 1992; Johannessen, 2000). Contamination of water supply from untreated healthcare waste such as infectious stools or bodily fluids can also have devastating effects.

Presently in Ghana, improper medical waste management practices are a source of most serious environmental problem in communities where they are generated. It exposes inhabitants to bad odors, smoke, contaminated water, and very toxic ash from nearby institutions that provide health care to residents in their vicinities. These hazards endanger the health of hospital staff, those who collect waste and clients that patronize these health care institutions. In Ghana medical Waste generated in this health care institutions are incinerated using the traditional De Montfort medical waste incinerator (Asante and Yanful, 2014). However due to lack of technologies for the treatment of medical waste in smaller clinics, some clinics turn to the bigger hospitals for assistance. Furthermore where the incinerator of the bigger hospitals is to incinerate large volumes of medical waste, and cannot handle the waste generated at the hospitals, the waste is then disposed off without proper treatment. Secondly, incineration of medical waste produces very harmful pollutants such as dioxins, furans and heavy metals, etc. into the environment which can have negative effects on the environment and human health (Pruss et al., 1999, World Health Organization, 2011).

Health care providers in Ghana are supposed to employ the best technologies to treat the waste they produce during their operations. However, due to inadequate funds to purchase more equipment, health care providers are unable to access efficient and environmentally sustainable treatment technologies. To have a better way of managing medical waste in Ghana it is important for managers to invent a management strategy for the healthcare centers in Ghana. It is also appropriate to understand and evaluate present activities in the management of waste generated by health care providers. Although extensive research has been carried out on waste management practices in Ghana, no single study exists which investigated the medical waste generation and management practices in the Cape Coast Teaching Hospital. This study assessed medical waste generation and management practices in the Cape Coast Teaching Hospital.

\section{Literature Review}

\subsection{Nature of Medical Waste}

There are varied opinions concerning the nature of medical waste to be managed. Writers in medical waste such as Crick (2012) clearly sees medical waste as any solid or liquid waste that is used in the diagnosis of diseases and the treatment of man when he falls ill. This definition was further expanded by Jang (2011) who indicated that medical waste are materials such as, culture dishes, other glassware, discarded surgical gloves and instruments, blood soaked bandages, discarded needles and lancets, cultures and stock and removable body organs. This has attracted scholars such as Agumuth who in 2010 argued that medical waste form a small part of Municipal Solid Waste (MSW) and world leaders should develop strategies to manage it because of its infectious or hazardous nature. However, in 2009 Rappe and Nyregen indicated that quantities of medical wastes generated each passing day from a wide range of sources is increasing and efforts must be made to curb it. According to them hazardous and toxic medical waste comes from medical facilities. This means that the major sources of medical waste emanate from hospitals and medical establishment in and around the world. The World Health Organization (WHO) concludes this identification crisis by providing two major categories of medical waste that can safely be used for this study (WHO, 1999): Non-hazardous medical waste is comparable to household waste and hazardous medical waste forms the part of waste that contains pathogenic organisms in quantities that can cause disease. 


\subsection{Medical Waste Generation and Management Practices in Ghana}

In Ghana, the chunk of medical waste is generated from healthcare facilities. They are obtained from the biostatistics or records units and out-patient department (OPD). According to Environmental Protection Agency (EPA), 2002), an average of $1.5 \mathrm{~kg} / \mathrm{bed} /$ day of healthcare waste is generated by health facilities in Ghana. The Cape Coast Teaching hospital generates an average daily waste of $35.12 \mathrm{~kg}$ and medical waste per patient per day was $0.1291 \mathrm{~kg} / \mathrm{patient} / \mathrm{day}$. The hospital generates both general and hazardous waste and there were no records (documents) on quantity of medical waste generated daily. As data on total waste generation rates at the hospitals were unavailable, the daily rates were computed using the bed complements of the selected hospitals and an average value of $1.5 \mathrm{~kg} / \mathrm{bed} / \mathrm{day}$, adopted from findings by a collaborative survey by the Environmental Protection Agency (EPA)-Ghana and the Ministry of Local Government and Rural Development of Ghana.

Medical Waste Management Practices in Ghana involves segregation and disposal. Segregation is the categorization of the waste according to its identity by Cheng et al. (2009). It is a vital process when dealing with medical waste in every waste management practice. Any error during segregation present a threat to those managing the medical wastes, Vorapong (2009). The segregation process is done at the point of waste generation by the person who generates the waste. When segregation is not carried out it is difficult to manage such waste when it is generated. Poor segregation defeats the principle of waste minimization. When segregation is not well done it could result in serious consequences on the environment and public and health. One of these consequences is the injuries it could cause to scavengers, children and the public (Weir, 2002).

After segregation the next activity that requires prudent caution is the handling of medical waste in plastic bag or rigid containers. Handling of medical waste according to Rappe and Nyregen (2009) takes place in all the department of the health facility. It is recommended that waste handlers are to handle it with caution considering the fact that the risk associated with medical waste may occur at any time (Hossain et al, 2011). To prevent injuries from sharp objects, handlers are to wear protective cloths and mask during waste disposal and incrimination (Fisman H. et al., 2007).

Another important step to consider when managing medical waste is the way these waste is stored. Some of the storage devices are plastic bags and rigid containers of various sizes. The World Health Organization recommends that waste should be taken away for disposal within 24 hours after its generation (WHO, 2010). A place should be developed by hospital management for temporary medical waste storage before they are transported to the final disposal sites (Insa et al., 2010) and this should be done by trained personnel. During the transportation medical waste should be documented and records should be kept on quantity and the type of waste being transported (Abdulla et al., 2008). The routes for transporting the waste should be designated to prevent it from getting into contact with patients. The time for the transportation of the medical waste within and outside the hospital should be determined to reduce the ability of it mixing with general waste (Kumari et al., 2012).

Medical waste treatment helps in reduction in volume, weight, risk of infectivity of the waste (Pruss et al., 1999). This is done to reduce the negative impact of medical waste on the environment and public health. The use of dumpsites, controlled landfill, and sanitary landfill are commonly found in developing countries. In the treatment of medical waste especially infectious waste, it should be grouped into burn and non-burn depending on the technologies used (Hossain et al., 2011). For example, autoclaving is adopted if the wastes to be treated are sharps objects such as needles (Jang 2006). Open pit dumping is commonly used for disposal of medical waste in developing countries because of the low cost (Al-Khatib and Sato, 2009). Open dumping is recognized as an infectious source of hazard to the environment (Al-Khatib and Sato, 2009). Medical waste management in Ghana faces the risk of cross contamination from the lack of thorough sorting of the waste at the points of generation and disposal sites.

\subsection{Acts and Legislation on Medical Waste Management}

The UNDP in 2002 set out a number of guidelines, policies and laws that have helped countries to protect its citizens against the potential effects of medical waste (UNEP, 2002). Moritz (1995) believed that when these laws, guidelines and policies are correctly carried out by the management of the waste, it can significantly reduce its impact. However, for managers to be effective, health facilities need to organize them very well in order to successfully implement policies, laws and guidelines. Abd El-Salam (2010) proposed that the organization of such policies and laws should ensure that health professionals and other waste handlers have sufficient knowledge of the waste they seek to manage. It is at this point that waste handlers can engage in proper practices that limit or eliminate infections and injuries within and outside the health facilities. It is for this reason that a lot of countries especially developing countries have developed guidelines that is aimed at handling and disposing medical waste from hospitals. Waste management committee in the hospitals needs to take and implement strategic decisions in other to minimize the health risks associated with medical waste (Insa et al., 2010).

Jamu et al. (2009) noted that Botswana passed a Waste Management Act in 1998 and a Medical Waste Management Code of Practice in 1996 to manage the waste that is generated by the various healthcare institutions. This act in Botswana serves as the foundation for training of medical workers on medical waste management. Also 
in South Africa the government has legislation on Hazardous Substance that was passed in 1983 and National Waste Management Act in 2008 amongst others (Waldner 2011). In conclusion it is observed from the above discussion that the development of laws and polices is so necessary in the managing of medical waste. It is also important to mention at this stage that the implementations of these laws are equally important.

\subsection{Potential Impacts Associated With Medical Waste}

Poor medical waste management is a major source of many communicable and infectious diseases in Ghana. According to WHO (2010), the potential effect of medical waste falls directly on the immediate communities, health staff, patients and the natural environment at large. Some of the potential effects of medical waste are injuries by shape objects such needles, infection from various wards, through poor handling and medical waste disposal. When medical waste is poorly managed and controlled it is likely to pollute water bodies, air and the environment as whole (Abor, 2007). The spread according to Olatoye (2009) could go into water bodies especially when it rains since at the dumpsite, especially in the case of flood then the effect will be far reaching from a local level to the National level. Infections from the poor handling of the medical waste could spread very fast among the handlers. Contagious disease is likely to be spread in the process which will pose danger to the communities where these waste in generated. Environmental workers at the hospital are the people at most risk from infectious medical waste. Some of the potential risk associated with poor collection of the waste, the storage and disposal of medical waste are not limited to environmental nuisances such as foul odors, flies, cockroaches, rodents and vermin. According to Mato and Kassenga (1997), diseases like cholera, typhoid and diarrhea can be transmitted because of poor handling of medical waste.

\section{Materials and Methods}

\subsection{Study Area}

This study assessed medical waste generation and management practices in the Cape Coast Teaching Hospital. Figure 1 shows the map of the study area. Cape Coast is the regional capital of the Central Region of Ghana and a fishing community. The Cape Coast Municipality lies within latitudes $5^{\circ} .07$ to $5^{\circ} .20$ north of the equator and between longitudes $1^{\circ} .11$ to $1^{\circ} .41$ west of the Greenwich Meridian. The Municipality covers a total land area of approximately $122 \mathrm{~km} 2$. It has a population of 118,106 (Ghana Statistical Service, 2000 Population and Housing Census).

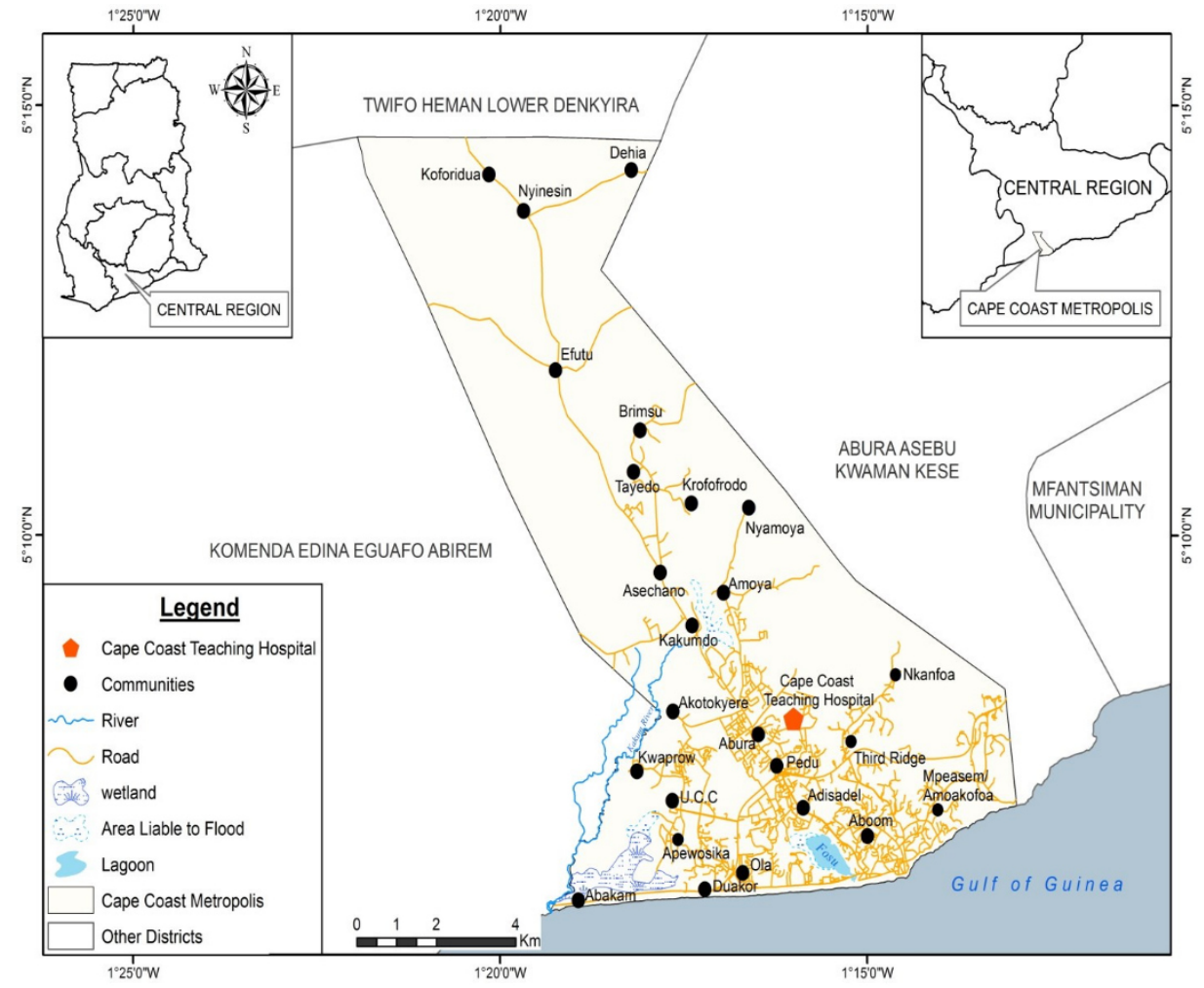

Figure 1: Map Showing Study Area

The hospital provides general healthcare and also serve as referral hospital to other hospitals in the region. In addition, the hospital serves as facility for medical students from the University of Cape Coast (U.C.C) in carrying out the practical aspect of their study. The hospital is government owned hospital and serves as a center of learning for several Nursing Training Colleges in the Region. 


\subsection{Research Design, Sample and Sampling Procedure}

The validity of any study is based on the systematic method of data collection and analysis. The present study used descriptive cross-sectional design based on survey method. The choice of this design was informed by the objective of the study - assessing and describing the medical waste generation and management practices in the Teaching Hospital using both quantitative and qualitative methods. The sample size for the target group was 74 . The proportional distribution of the sample size from the various categories of employees is presented in Table 1 below.

Table 1: Proportional Distribution of the Sample Size from the Various Categories of Hospital Employees

\begin{tabular}{lcc}
\hline Staff & Sample frame & Sample size \\
\hline Ancillary Staff & 22 & 16 \\
Nurse & 41 & 30 \\
Pharmacist & 5 & 4 \\
Doctor & 21 & 16 \\
Laboratory Staff & 8 & 6 \\
Radiographer & 3 & 2 \\
Total & $\mathbf{1 0 0}$ & $\mathbf{7 4}$ \\
\hline
\end{tabular}

\subsection{Data Collection}

The study was carried out between May and August 2015. Mixed method approach was used to collect data for the study. This method helps in inferring both qualitative and quantitative data in a single study or in sequential studies based on priority and sequence of information (Green and Caracelli, 1989). Site visits was done by the researchers, key informant interviews were also conducted and designed questionnaires were administered to 74 hospital employees to collect data about knowledge of medical waste generation, separation, collection, storage, transportation, and disposal. The sample size of 74 respondents is considered adequate to represent the characteristics of the entire population. During site visits, predesigned observation checklist was used based on Ghana Ministry of Health Medical Waste Management Policy and guided by the literature reviewed (Ghana Health Service, 2006). In order for the researchers to ascertain medical waste management challenges facing the hospital, interview guide was used for all the management members, key unit heads, the environmental health officer and the leader of waste workers at the hospital. Quality control measures such as the need for independent completion of the questionnaires and freedom of participation or withdrawal from the study were followed. Efforts were also made to minimize methodological, personal and social desirability biases.

\subsection{1: Medical Waste Measurement (Quantification)}

Measurement of quantities of medical waste generated per day was done at the various units of the hospital over a four month period (May 2015 to August 2015). The quantity of hospital waste generated per day was measured in kilogram using the Salter Albion Weighing Scale (Pruss et al., 2013). Initial weight of the empty waste container was taken after which wastes was placed in the container and weighed. The weight of the empty container was then deducted from the weight to get the actual weight of the waste generated. Infectious wastes measured included stained cotton wool, surgical gloves, swabs as tubing, disposable towels, gloves, laboratory coats and sharps (e.g. hypodermic needles and syringes, intravenous needles, scalpels, lancets blades).

\subsection{2: Segregation of Waste}

In order to segregate infectious wastes from non-infectious wastes, waste handlers and hospital staff involved directly or indirectly in the management of waste were educated and sensitized to segregate waste. After the education waste containers (black polythene bags designated for general waste, yellow polythene designated for infectious waste and hard card boxes designated for sharps) were made available to the various units (departments) for the segregation process at source. The segregation process was done for duration of one month. Medical wastes produced from the various units of the hospital were grouped into sharps, pathological, infectious and pharmaceutical wastes. The objective of this was to determine the level of compliance. The composition of medical waste at the Cape Coast Teaching Hospital is shown in Table 2.

Table 2: Composition of Medical Waste Generated in the Cape Coast Teaching Hospital

\begin{tabular}{ll}
\hline \multicolumn{1}{c}{ Types of medical Waste } & \multicolumn{1}{c}{ Composition of Medical Waste } \\
\hline Sharps & $\begin{array}{l}\text { Hypodermic needles and syringes, intravenous needles and tubing, scalpels } \\
\text { lancets saws, blades, broken glass and nails. }\end{array}$ \\
& $\begin{array}{l}\text { Sponges, Soiled dressings, Cotton wool, Surgical gloves, and Swabs as tubing } \\
\text { and filters, disposable towels, gowns and aprons, gloves and laboratory coats. }\end{array}$ \\
Pharmaceuticals & $\begin{array}{l}\text { Expired drugs and their containers. Bottles or boxes with residues, gloves, } \\
\text { masks, connecting tubing, and drug vials. }\end{array}$ \\
Pathological waste & Tissues, organs such as Fetuses and placentas \\
\hline
\end{tabular}

\subsection{3: Quantitative Data Collection}

The quantitative data was gathered using structured questionnaire. The questionnaire was prepared administered 
to six categories of hospital staff comprising Doctors, Nurses, Radiographers, Pharmacists, Laboratory and Ancillary Staff purposively selected from the different departments (units) of the hospital. The ancillary staff were included in the study since they handle waste at the hospital. Seventy four (74) questionnaires were distributed to various categories of these health workers. The questionnaire covered quantity of waste generated, segregation, collection, internal and external storage, transportation, treatment and disposal of medical waste in the Cape Coast Teaching hospital. Prior to the administration of the questionnaires to the respondents, the reason for the study was explained to them and procedures for completing the questionnaires were also discussed with them. All the participants participated on voluntary basis. Quality control measures such as the need for independent completion of the questionnaires were followed. This was to eliminate social desirability issues from the responses. This procedure was replicated throughout the administration of the questionnaires in all the departments.

\subsection{4: Interview}

An interview schedule prepared was quite simple and understanding for the respondents to express their opinion freely. Adequate care has been taken to collect unbiased data. Personal interviews were conducted to obtain indepth and comprehensive primary data on medical waste management practices within the hospital. Personnel interviewed included contractors of the private company responsible for the collection and disposal of medical waste, health and safety officers of the Cape Coast Teaching Hospital. Prior consent and appointments were made with the key informants (interviewees) before visits were made to their designated offices by the researchers for the interview. Interview session for each interviewee lasted between 20-30 minutes and the session was recorded using sound digital recorder.

\subsection{5: Observational Survey}

To find out the current hospital waste management practices within the hospital, a week was spent at the hospital observing how medical waste is managed daily. The hospital was visited to obtain information on common practices in the management of medical waste. This was done within a period of eight (8) weeks (July 2015 to August 2015). Checklist observation guide developed based on Ghana Ministry of Health Medical Waste Management Policy and guided by the literature was used for this purpose. All the visits to the study site were uninformed (unannounced) and were helpful in getting information about the day to day activities in the management of medical waste at the hospital. The observations were carried out to gather data to validate the information obtained from the interviews and questionnaires administration. The researchers observed processes from the point of medical waste generation to final disposal site to obtain first-hand information. The researchers visited the hospital for one week, observing how medical waste is managed daily then proceeded to where medical waste is incinerated and landfill where medical waste is finally disposed of. Measurements and recordings were done to express observations numerically in order to find out relationships between waste generated and the number of people who visit the hospital on daily basis. Quantities of medical waste generated at the hospital were measured. The number of patients who visited the selected hospital per day was also recorded. Observations made during the field work were captured using reflective logs and digital camera (Plates 1, 2, 3 \& 4).

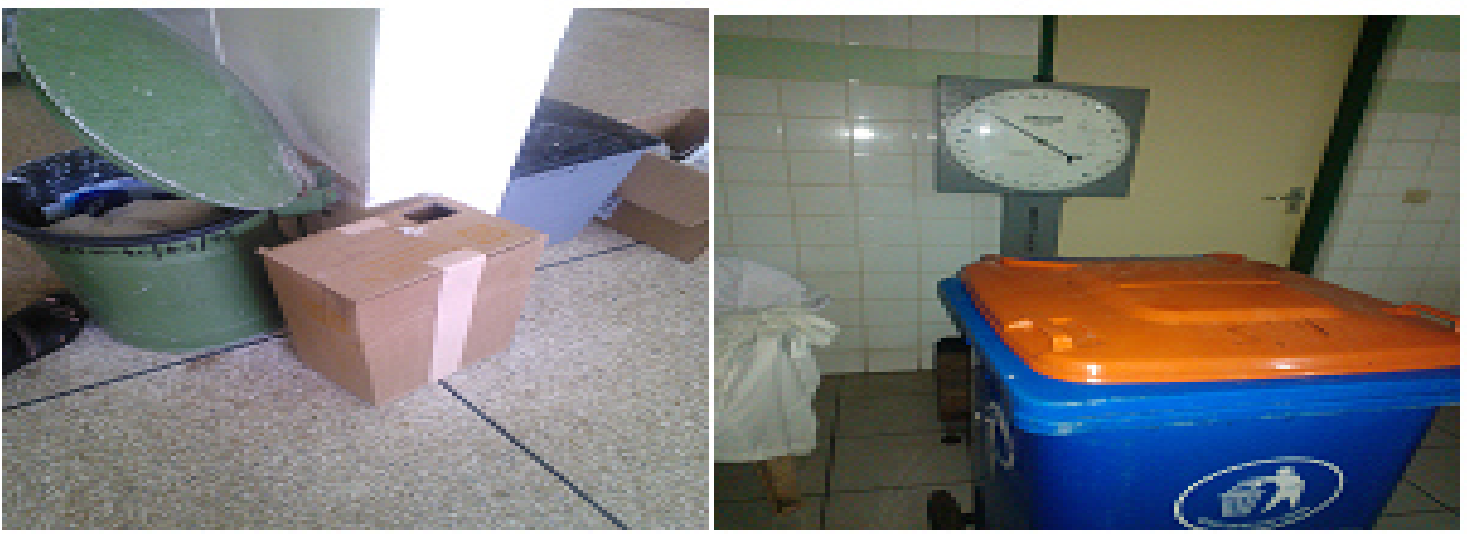

Plate 1: Sharps collected in ward

Plate 2: Medical been weighed 

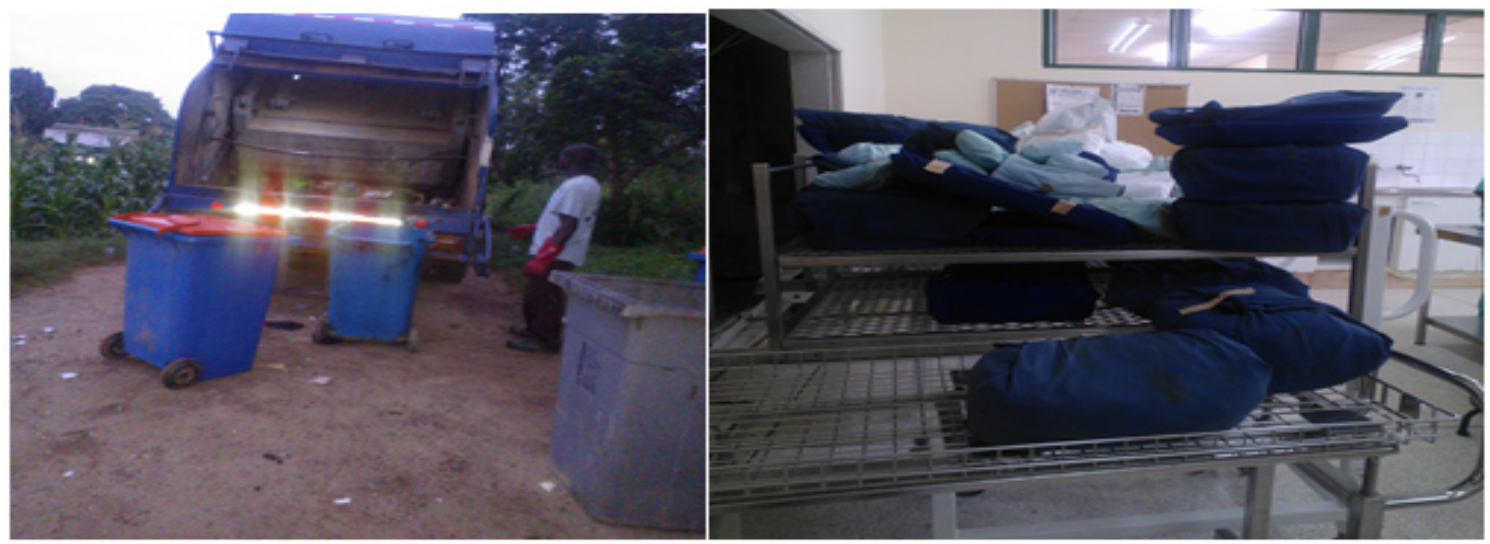

Plate 3: Waste van ready for waste collection Plate 4: Medical waste for incineration

\section{4: Validity, Reliability and Ethical Consideration}

The validity and reliability of the research depends to a greater extend how properly the questionnaire is designed and administered (Mackison D. et al., 2010). Here the questions to be put to respondent were adequate and the objective of the questionnaire was clearly defined. To achieve reliability and validity quality training were given to interviewers to skillfully handle prospective respondents and efficiently administer the survey instruments. Also the survey instruments were pre-tested to enable the researchers' correct shortcoming of some of the questions set to make it suitable for collecting the required data. Test item and scale reliability were finally determined using Cronbach Alpha statistics. A formal permission was obtained from management of the Cape Coast Teaching Hospital to enable the researchers conduct the study. The objective of the study was explained to each study participant and they agreed to participate. Freedom to exit the survey by participants was freely adhered to.

\section{5: Data Processing and Analysis}

Analysis of the quantitative data obtained using the questionnaires was done using SPSS Version 20.0 Programme. Test items reliability and internal consistency were determined using Cronbach's alpha statistics (Cronbach, \& Richard, 2004). The calculated values (0.89) were greater than 0.8 indicating that items on the instruments have sufficient internal consistency (Pallant, 2011; Cronbach \& Richard, 2004). Descriptive statistics and t-statistics were applied to the quantitative data. Data analysis was done at 0.05 (95\%) confidence interval. Data was then represented in tables using Microsoft Excel Software Version 11.

The recorded transcripts of interview sessions were first transcribed into Microsoft Word for Windows and edited daily to get the clear transcriptions of the interviewees' accounts. This was then subjected to thematic content analysis procedure described in Krippendorf (2004); Miles et al., (1994) to identify the various emerging themes. The data was then described in detailed using manifest and deductive procedures.

\section{Results}

The study assessed medical waste generation and management practices in the Cape Coast Teaching Hospital. Data was collected from 74 hospital employees using structured questionnaire, interview and observational survey. The quantitative and qualitative data obtained are presented below.

\subsection{Qualitative Data Presentation}

Tables 3-7 summarised the quantitative data gathered from the study. 
Table 3: Demographic Profile of Respondents

\begin{tabular}{clccl}
\hline Character & Variation & Total & Percentage (\%) & \\
\hline \multirow{3}{*}{ Age } & $21-30$ & 37 & 50 & \\
& $31-40$ & 20 & 27 & Mean Age $=18.50$ \\
& $41-50$ & 12 & 16 & $\mathrm{SD}= \pm 13.77, \mathrm{p}>0.05$ \\
& 51 and above & 5 & 6.8 & \\
Sex & Male & 36 & 48.6 & Mean $=37.00$ \\
& Female & 38 & 51.4 & $\mathrm{SD}= \pm 1.41, \mathrm{p}<0.05$ \\
& Ancillary staff & 52 & & \\
Occupation & Nurses & 14 & 67.5 & \\
& Pharmacist & 4 & 18.2 & $\mathrm{Mean}=16.67$ \\
& Doctors & 3 & 3.2 & $\mathrm{SD}= \pm 14.40, \mathrm{p}<0.05$ \\
& Lab staff & 2 & 2.9 & \\
Working & Radiographers & 2 & 2.6 & \\
Experience (years) & $0-5$ & 43 & 58.1 & \\
& $6-15$ & 17 & 23 & \\
\hline
\end{tabular}

Source: Field survey, 2015

Table 4: Quantities of Medical Waste Generated vis-a-vis the Number of Patients Visiting the Hospital Daily Over a One Week Period

\begin{tabular}{lccccccc}
\hline & Monday & Tuesday & wed & Thursday & Friday & Saturday Sunday \\
\hline Number of patients per day & 287 & 254 & 269 & 300 & 276 & 258 & 307 \\
$\begin{array}{l}\text { Medical waste generated } \\
\text { in kilogram(kg) }\end{array}$ & 35.52 & 28.69 & 26.85 & 38.94 & 34.74 & 29.47 & 32.56 \\
Generation rate kg/patient/day & 0.124 & 0.113 & 0.099 & 0.129 & 0.126 & 0.114 & 0.106
\end{tabular}

Source: Field survey, 2015

Table 5: Mean Quantity and Composition of Solid Medical Waste Generated In the Cape Coast Teaching Hospital

\begin{tabular}{lcccccc}
\hline \multicolumn{1}{c}{$\begin{array}{c}\text { Types of } \\
\text { Medical Waste } \\
\text { Produced }\end{array}$} & Theatre & $\begin{array}{c}\text { Hospital Units/Departments and Quantity of Waste Produced } \\
\text { Laboratory }\end{array}$ & $\begin{array}{l}\text { Female } \\
\text { wards }\end{array}$ & $\begin{array}{l}\text { Male } \\
\text { ward }\end{array}$ & $\begin{array}{c}\text { Out Patient } \\
\text { Department }\end{array}$ & $\begin{array}{c}\text { Quantity } \\
\text { (kg) }\end{array}$ \\
\hline $\begin{array}{l}\text { Sharps } \\
\text { Infectious }\end{array}$ & 12.32 & 9.58 & 10.89 & 10.66 & 2.00 & 45.45 \\
Pharmaceutical & 16.52 & 3.12 & 14.78 & 24.27 & 0.00 & 58.69 \\
Pathological & 2.46 & 2.51 & 17.20 & 10.41 & 0.00 & 32.58 \\
& 28.48 & 0.00 & 0.00 & 0.00 & 0.00 & 28.45 \\
Total (Kg) & $\mathbf{5 9 . 7 8}$ & $\mathbf{1 5 . 2 1}$ & $\mathbf{4 2 . 8 7}$ & $\mathbf{4 5 . 3 4}$ & $\mathbf{2 . 0 0}$ & $\mathbf{1 6 5 . 2}$ \\
\hline Sourc: Fin
\end{tabular}

Source: Field survey, 2015 
Table 6: Response to Storage of Medical Waste Awaiting Transportation (a) Response to Storage of Medical Waste Awaiting Transportation

\begin{tabular}{lcc}
\hline Response & Total & Percentage (\%) \\
\hline Secure & 64 & 86.49 \\
Insecure & 10 & 13.51 \\
Total & $\mathbf{7 4}$ & $\mathbf{1 0 0 . 0}$ \\
\hline
\end{tabular}

(b): Percentage Rating of The Effectiveness of Medical Waste Management Practices in The Hospital

\begin{tabular}{lcc} 
Response & Total & Percentage (\%) \\
\hline Very Good & 38 & 51.35 \\
Good & 33 & 44.59 \\
Poor & 3 & 4.05 \\
Total & $\mathbf{7 4}$ & $\mathbf{1 0 0 . 0}$ \\
\hline
\end{tabular}

(c): Mode of Transportation of Medical Waste To Onsite Area For Final Collection

\begin{tabular}{lcc} 
Receptacle & Total & Percentage (\%) \\
\hline Trolleys/Dustbins & 56 & 75.68 \\
Color coded bags/Trash bags & 18 & 24.32 \\
Total & $\mathbf{7 4}$ & $\mathbf{1 0 0 . 0}$ \\
\hline
\end{tabular}

(d): Training on Medical Waste Management

\begin{tabular}{lcc}
\hline Response & Total & Percentage (\%) \\
\hline Yes & 47 & 63.51 \\
No & 27 & 36.49 \\
Total & $\mathbf{7 4}$ & $\mathbf{1 0 0 . 0}$ \\
\hline
\end{tabular}

(e): Access on Document For Medical Waste Management

\begin{tabular}{lcc}
\hline Response & Total & Percentage (\%) \\
\hline No & 48 & 64.86 \\
Yes & 26 & 35.14 \\
Total & $\mathbf{7 4}$ & $\mathbf{1 0 0 . 0}$ \\
\hline
\end{tabular}

Source: Field survey, 2015

Table 7: Summary Results of Descriptive and T-test Statistics of Quantitative Data

\begin{tabular}{|c|c|c|c|c|c|c|c|}
\hline \multirow[b]{4}{*}{ Constructs } & \multicolumn{7}{|c|}{$[\mathbf{N}=74 ;$ Cronbach Alpha Statistics $=0.89]$} \\
\hline & \multirow{2}{*}{\multicolumn{2}{|c|}{$\begin{array}{l}\text { Descriptive } \\
\text { Statistics }\end{array}$}} & \multicolumn{5}{|c|}{ T-Test Statistics } \\
\hline & & & \multirow[t]{2}{*}{$\begin{array}{c}c t \\
\text { value }\end{array}$} & \multirow[t]{2}{*}{ p-value } & \multirow[t]{2}{*}{$\begin{array}{c}\text { Mean } \\
\text { Difference }\end{array}$} & \multicolumn{2}{|c|}{$\begin{array}{l}95 \% \text { CI of the } \\
\text { Difference }\end{array}$} \\
\hline & Mean & $\mathbf{S D} \pm$ & & & & Lower & Upper \\
\hline \multicolumn{8}{|l|}{ Demographics Profiles } \\
\hline Age & 18.50 & 13.77 & 2.69 & .075 & 18.50 & -3.41 & 40.41 \\
\hline Sex & 37.00 & 1.41 & 37.00 & .017 & 37.00 & 24.29 & 49.71 \\
\hline Occupation & 16.67 & 14.40 & 2.83 & .036 & 16.66 & 1.55 & 31.78 \\
\hline \multicolumn{8}{|l|}{ Waste Generation } \\
\hline Quantity of Medical Waste & 278.71 & 20.26 & 36.39 & .000 & 278.71 & 259.97 & 297.45 \\
\hline Rate of Waste Generation & 18.50 & 24.42 & 1.52 & .227 & 18.50 & -20.36 & 57.36 \\
\hline \multicolumn{8}{|l|}{ Waste Management Practices } \\
\hline $\begin{array}{l}\text { Effectiveness of Medical Waste } \\
\text { Management }\end{array}$ & 19.75 & 18.32 & 2.16 & .120 & 19.75 & -9.40 & 48.89 \\
\hline Waste Storage Receptacles & 24.67 & 8.74 & 4.89 & .039 & 24.66 & 2.96 & 46.37 \\
\hline Mode of Transport of Waste & 37.00 & 26.87 & 1.95 & .302 & 37.00 & -204.42 & 278.42 \\
\hline Storage of Medical Waste & 37.00 & 38.18 & 1.37 & .401 & 37.00 & -306.07 & 380.07 \\
\hline $\begin{array}{l}\text { Training of Waste Management } \\
\text { Personnel }\end{array}$ & 37.00 & 14.14 & 3.70 & .168 & 37.00 & -90.06 & 164.06 \\
\hline
\end{tabular}




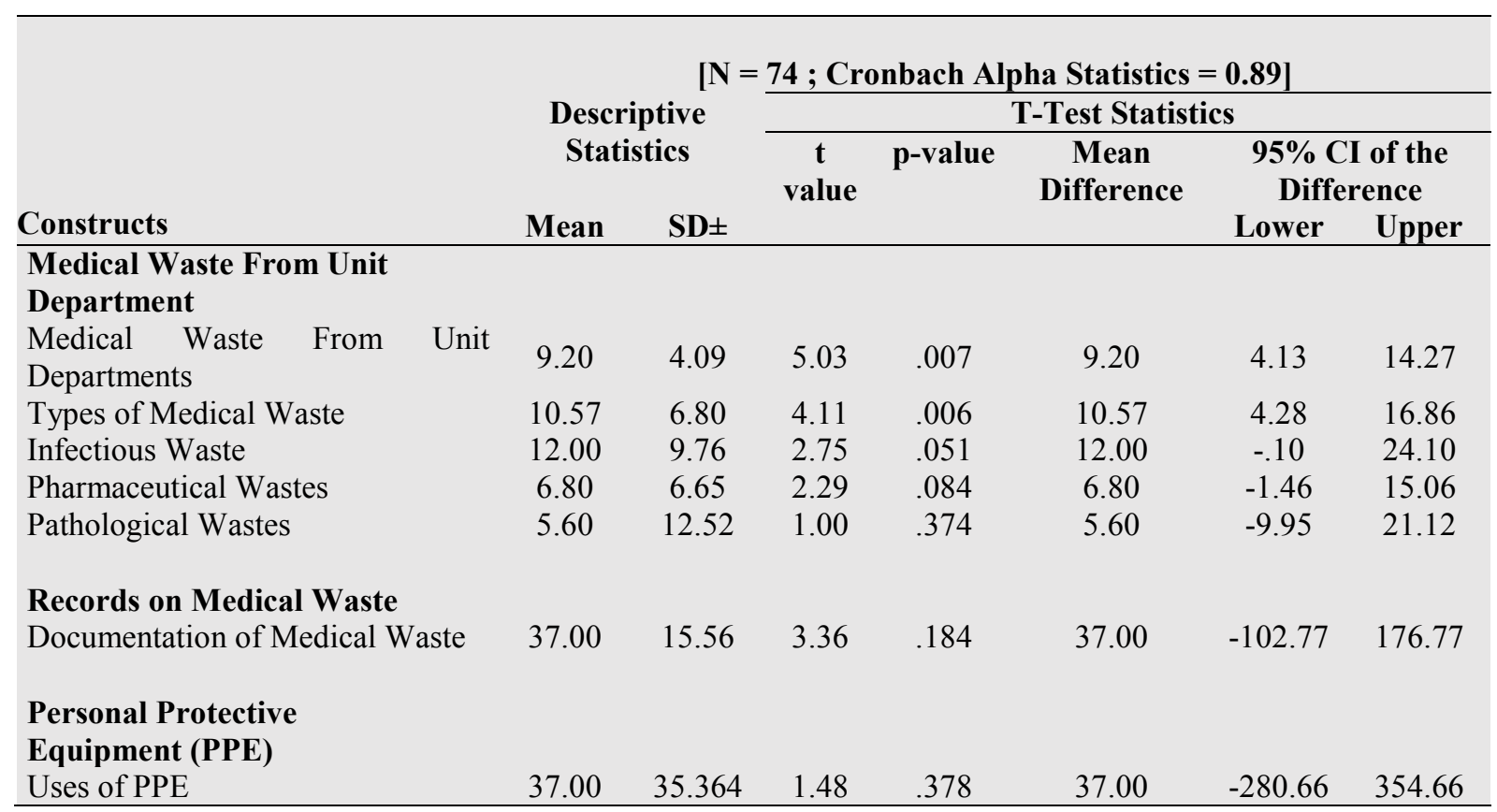

The obtained results concerning the mean parameter estimates, standard deviations and t-statistics measures are presented in Table 7 above. Most of the parameter estimates were significant at the 0.05 significance level.

\section{2: Qualitative Data Presentation}

4.2.1: Summary of Interview Results on Medical Waste Management Practices in the Cape Coast Regional Hospital

On the issue of training waste management personnel this is what the Environmental Health Officer at the Cape Coast hospital had to say:

“...there was no scheduled programs for training on medical waste management in the hospital." (Interview with Environmental Health Officer, Cape Coast Regional Hospital).

When interviewed on the medical waste management practices within the hospital, the contractors of the private company responsible for the collection and disposal of medical waste explained:

"...The hospital generates two types of medical waste; general or non-hazardous waste and hazardous waste. The general compositions of the waste were sharps, general waste or non-infectious waste, human tissue and organs waste, used bandages, toilet paper, gloves and sanitary towels. The noninfectious waste formed the bulk of the waste generated. Non-infectious (general/municipal) wastes often produce foul odours, are unsightly, and attract rodents and insects. The wastes are segregated using colored bags and containers are used in storing the different types of hazardous waste generated as prescribed by the Ghana Health Service (GHS). He further stated that the hospital staff that use sharps were required to drop them into safety boxes but this was not strictly followed." (-interview with contractor of the private company responsible for the collection and disposal of medical waste at the Cape Cost Regional Hospital).

On the issue of management practices that could help address the chunk of hospital waste generated, these are the suggestions from the cross-session of the respondents:

"...there is the need for the hospital to have incinerators, adequate waste bins, training sessions for waste handlers and thorough segregation of waste generated daily." (-interview with a cross-session of the respondents).

Concerning the issues of personal protective equipment (PPE) used by the waste handlers, in the hospital, this what the respondents said:

".... we use over coats, goggles, wellington boots, nose cover and hand gloves with the later constituting the major PPE." (-interview with cross-section of waste handlers in the hospital).

\section{Discussion}

\subsection{Demographics Profile of Respondents Knowledge on Medical Waste Management}

The demographic profiles of participants (Table 3 above) showed that there were slightly more female $(51.4 \%$ than male (48.6\%). The age distribution of participants' also shows that majority of them belonged to age group of 21-30 with mean age of 18.50 and standard deviation of 13.77 (Table 7). The descriptive and t-test statistics results captured in Table 7 above also showed that most of the variables were statistically significant. In terms of 
occupation, the ancillary staff constitutes the majority $(67.5 \%$, mean $=16.67, \mathrm{SD}= \pm 14.40, \mathrm{p}<0.05)$. Majority $(58.1 \%)$ of the respondents had at least 5 years working experience in the hospital.

\subsection{Medical Waste Generation and Management Practices in the Cape Coast Teaching Hospital}

Medical waste management is a significant environmental and social obligation, and hence requires a proper plan. The hospital waste management plans are devised to incorporate a standard protocol for effective management of waste disposal. This study assessed existing medical waste generation and management practices in the Cape Coast Teaching Hospital. The results of the study revealed that the Cape Coast Teaching Hospital averagely attends to about 272 patients a day and consequently generates about $35.12 \mathrm{~kg}$ of medical waste daily $($ mean $=278.71, \mathrm{SD}=$ $20.26 ; \mathrm{t}=36.39, \mathrm{p}<0.05)$. This corresponds to about 1089 patients in a month. Various studies have demonstrated that the total volume of waste generated from an institution is often related to the type or size of the institution (Bdour et al., 2007; Cheng et al., 2009; Patwary et al., 2009). Additionally more waste is generated depending on patients visiting the hospital; and usually high numbers are associated with public hospitals, the type of healthcare facility and the service being provided at the facility; others are the number of beds, the current economic, social and cultural status of the patients as well as the general condition of the area where the hospital is located (Nemathaga et al., 2008). The amount of waste also depend to a very large extend on the level of technology used in managing it. Other writers have argued that medical waste generation also depends on the service that the hospital provides. These reasons agree with the assertions of various authors in similar studies such as Coker et al., 1999; Mato and Kaseava, 1999; Pruss and Townsend, 1998; Waseem et al., 1995. They all concluded that the variations in the rate of waste generated from one ward or unit to another within the hospital is dependent upon the nature of activities or services in that particular ward.

The results of the study indicated that there were varying amount and composition of the medical wastes generated depending on the unit of the hospital (mean $=9.20, \mathrm{SD}=4.09, \mathrm{t}=5.03, \mathrm{p}<0.05$ ). Theatre waste was highest $(59.78 \mathrm{~kg})$, followed by the male ward $(45.34 \mathrm{~kg})$, and the female and maternity wards $(42.87 \mathrm{~kg})$. (Kgosiesele and Zhaohui, 2010). The other patients who are seen at the Out-Patient-Department (OPD) and admitted are also moved to these wards for treatment. The laboratory unit was fourth from the study while the OPD recorded the least of all the department in terms of medical waste generation. There are two types of medical waste generated at the hospital; general or non-hazardous waste and hazardous waste. The general compositions of the waste were; sharps $(10.81 \%)$, general waste or non-infectious waste $(54.04 \%)$, human tissue and organs waste $(9.46 \%)$ and used bandages, toilet paper, gloves and sanitary towels $(25.69 \%)$. The non-infectious waste formed the bulk of the waste generated. The Ghana Health Service statistics shows that about 70-90 percent of medical waste is often general waste and $10-25 \%$ hazardous waste (GHS, 2002). Infectious hospital waste, no matter how small, poses a health threat. The infectious hospital waste constituted a small fraction of the entire hospital waste. Infectious hospital wastes have the ability to spread deadly diseases or cause personal injuries. For this reason waste handlers should be very careful in the handling of waste. This means that it must be properly marked, and disposed of. The World Health Organization (1999) data also shows that about $85 \%$ of waste generated by the hospital is non-hazardous, $10 \%$ are infectious, while around $5 \%$ are non-infectious but hazardous. Non-infectious (general/municipal) wastes often produce foul odours, are unsightly, and attract rodents and insects.

The relatively large quantities of wastes generated at the hospital were from disposable instruments (Shaner and McRae, 2002). Bdour et al., (2006) have reported the average waste generation in European Healthcare Establishments to be $3.9 \mathrm{~kg} / \mathrm{bed} /$ day in Norway, $4.4 \mathrm{~kg} / \mathrm{bed} /$ day in Spain and $3.3 \mathrm{~kg} / \mathrm{bed} /$ day in the UK and France. Results from this study revealed that the estimated medical waste per patient per day was $0.1291 \mathrm{~kg} / \mathrm{patient} / \mathrm{day}$ which were lower than the standard of medical waste generation of $0.20 \mathrm{~kg} /$ patient/day for developing countries (WHO, 2015). This suggests that there is a wide gap between the developed nations and developing countries in terms of medical care provision (Nemathaga et al., 2008).

The management practices of medical waste generated in the cape coast teaching hospital was segregation. The study showed that most of the units within the hospital segregate their infectious wastes at source. About $98.6 \%$ of respondents indicated that the medical wastes generated from the hospital were segregated and $94.8 .0 \%$ was satisfied with the level of segregation. The Cape Coast Hospital also used coloured bags and containers in storing the different types of hazardous waste generated as prescribed by the Ghana Health Service (GHS) (mean $=24.67$, $\mathrm{SD}=8.74, \mathrm{t}=4.89, \mathrm{p}<0.05)$. About $43.24 \%$ of the waste was segregated into boxes, $36.49 \%$ into metal dust bins and $20.27 \%$ into color coded bags. Similar observations were reported by Phengxay et al., (2005) in Lao People's Democratic Republic, Mbongwe et al., (2008) in Botswana and Bdour et al., (2006) in Jordan. It was observed that health staffs that use sharps were required to drop them into safety boxes but this was not strictly followed. In Brazil, a study conducted by Da Silva et al., (2005) in some public clinics demonstrated strict adherence to using rigid, puncture proof, yellow containers with the international hazardous waste logo in segregating waste.

From the study, it was also discovered that over $86 \%$ of the medical waste staff indicated that the security of the medical waste on the hospital premises while waiting to be transported to its final destination was adequate. This was because the medical waste was kept in bins and covered. Vorapong, (2009), suggested that waste 
containers, should be covered always with lids during transport and storage. The Cape Coast Teaching Hospital waste bins were mostly hard card boxes, metal containers and polythene bags. The hospital did not have its own vehicle for the transportation of medical waste and had to rely on a private company, Zoomlion, which had a purpose built vehicle for medical waste transport. The vehicles were fully enclosed and seamless. The drivers were not protected using the WHO standards which emphasizes that drivers must at all times carry consignment documents detailing the Health Care Risk Waste (HCRW) being transported. The usual way of transporting medical waste to storage site at the hospital was done by the use of 240 litre dust bins and 80 litre dust bins (76.6\%) and trash bags $(23.4 \%)$. They were used as an easier and safer way of transferring medical waste to the temporary storage site.

On the disposal of waste, about $90 \%$ of the medical waste was disposed off by the private company with about $10 \%$ of pathological waste, such as placentas, given to patients for disposal at their homes though the hospital disposed some in an improvised incinerator. It was noted that Cape Coast Teaching Hospital does not have a structure or facility for dealing with medical waste. Oweis et al. (2005) noted that the medical waste management teams play a pivotal role in the successful implementation of a HCW management plan.

\section{3: Training on Medical Waste Management}

From the study, majority (63\%) of those who directly handle waste at the hospital had received some level training. However, the hospital has no formal programme for training of personnel on waste management practices (mean $=37.00, \mathrm{SD}= \pm 14.14, \mathrm{t}=3.70, \mathrm{p}>0.05$. This evidence was supported by two views. First, the Environmental Health Officer at the Cape Coast hospital, reported that there was no scheduled programs for training on medical waste management in the hospital. Second, the World Health Organization (WHO, 2005) reports confirmed that there was very little training of personnel on medical waste management in hospitals and this phenomenon is more observed in developing countries. According to the WHO (2004) the level of education of and the type of training medical waste handlers receive are very important for the proper management of the waste they seek to handle (WHO 2004). This provides initial awareness on the risks associated with their work and safety practices that should be ensured. The medical waste management team at the Cape Coast Teaching Hospital is directly under the supervision of the Environmental Health Officer. Similar study conducted by Diana (2002), also stipulates that those who train waste handler should equip them with the needed skills in order to enable them handle the waste properly in order to prevent spill over and minimize their public health and environmental impact. Hem (1999), also recommended that waste managers in the hospitals should spell out a well-planned training programs for all waste handlers. The Environmental Health Officer at the Cape Coast hospital, however, reported that there was no scheduled programs for training on medical waste management. This supported the observation that there was no documentation of medical waste generation in the hospital. Most of the training was acquired on the job. Even though there were limited or no formal training programs, most healthcare workers responsible for medical waste management had good knowledge on waste management due to the long service and experience gained on the on job. There is therefore the need to put in place a more organized training programme for personnel on how to handle infectious and hazardous waste as well as receive preventive medical treatment and proper supervision. This, according to Verma (2010 and Roe Gillis, 2012) must be supported effective monitoring and proper supervision.

\section{4: Handling of Medical Waste and Onsite Transportation}

The survey showed that waste handling at the Cape Coast Hospital was generally good. The workers were observed to be handling waste very well using the appropriate personal protective equipment (PPE) (health and safety tools including gloves and mouth masks (mean $=37.00, \mathrm{SD}=35.36, \mathrm{t}=1.48, \mathrm{p}>0.05$ ). This was also evidence during the interview with cross-sections of medical waste handlers in the hospital where they indicated that they use over coats, goggles, wellington boots, nose cover and hand gloves with the later constituting the major PPE. This is a good practice considering the infectious nature and bad odour emanating from the waste. Use of nose mask, safety boots and puncture-proof gloves were common (Pratt et al., 2001; Clark et al., 2002; Expert Advisory Group on AIDS and the Advisory Group on Hepatitis, 1998). Birpinar et al. (2009) also presented similar results that showed that some medical waste collectors in some healthcare facilities in Istanbul, Turkey wore appropriate personal protective equipment. Mochungong (2010) also reported that a greater number of waste handlers in Cameroon used protective tools to protect workers in the Northwest Region of Cameroon. This is in line with what Abor reported (2007) about the Kotuba hospital in South Africa, where the workers adhered to strict waste management guidelines by using protective equipment.

The study also found that the hospital has the responsibility for transporting waste from the wards to a designated place outside the hospital, from there a waste disposal company is contracted to transport the waste from the hospital disposal site to a land fill site in the Cape Coast Metropolis. Majority of respondents (75.68\%) indicated dustbins as the means of transportation to the temporal disposable site. These transportation systems appear to be the accepted practice because countries like Malaysia and china and South Africa are doing the same 
thing (Insa et al., 2010). Though there was a Department for Waste Management at the Cape Coast Teaching hospital, there were no records (data) on the quantity of waste generated in the hospital. Non-segregation of waste was also practiced by some units of the hospital.

\section{Conclusion}

Understanding waste management practices at the healthcare centres is crucial for achieving Sustainable Development Goal (SDG) 12 which sets the target, by 2030, there is substantially reduced waste generation through prevention, reduction, recycling and reuse. This study assessed medical waste generation and management practices in the Cape Coast Teaching Hospital. The results of the study revealed that Cape Coast Teaching Hospital generates an average daily medical waste of $35.12 \mathrm{~kg}$. This was dependent on type and size of the hospital and the number of patients visiting and the services provided. The hospital generated both general and hazardous waste. There were no records (documents) on quantity of daily medical waste generated in the hospital. However, medical waste management practices was enforced using the recommended equipment and following the protocols of the Ghana Health Service (GHS). Nevertheless, there were some waste management challenges such as proper documentation of medical waste generated, which needed to be addressed to ensure sustainability in waste management practices in the hospital.

\section{Recommendation}

There should be proper documentation on the quantity of medical waste generated per day/week/month/year to serve as a guide for effective and efficient planning. This will help hospital management to make informed decisions about the amount of medical waste generated and its management. The hospital should develop key yardstick to measure and compare its waste management practice with best practices at similar hospitals in Ghana and the world over. An incinerator should be provided to the hospital to help in the proper incineration of combustible medical waste. The hospital should also provide different types of receptacles to enable effective segregation of daily waste generated. Environmental officer should follow up waste collected to make sure that they are appropriately treated and disposed of according to Environmental Protection Law. The Ministry of Health $(\mathrm{MoH})$ should from time to time conduct an evaluation of medical facilities to ensure that the hospital does respect safety measure set out by the ministry.

\section{Acknowledgements}

The authors are deeply grateful to the staff of Cape Coast Teaching Hospital for their support in the research.

\section{Conflict of Interest}

The authors declare no conflict of interest.

\section{Authors' Contributions}

${ }^{1}$ Conceptualization, Data Curation, Methodology, Investigation, Project Administration, Writing Original Script, and Formal Analysis.

${ }^{2}$ Data Curation, Methodology, Investigation, Writing, Formal Analysis, Validation, Review and Editing;

${ }^{3}$ Data Curation, Methodology, Investigation, Writing, Formal Analysis, Review and Editing.

$1,2,3$ Final approval of completion of the article.

\section{References}

Abd El-Salam, M.M. (2010). Hospital waste management in El Beheira Governorate Egypt. Journal of Environmental Management, 91: 618-629.

Abdulla, F., Qudais, H.A. and Rabe, A. (2008). A site investigation of medical waste management practices in Northern Jordan. Journal of Waste Management, 28(2): 450-458.

Abor, P.A. (2007). Medical Waste Management Practices in a Southern African Hospital. Journal of Applied Science Environment Management, 11(3): 91-96.

Agumuth, P. (2010). Waste management in developing Asia: Can trade and cooperation help? The Journal of Environment and Development, 17(1): 1-25.

Al- Khatib, A. and Sato, C. (2009). Solid healthcare waste management: Status of healthcare centers in the West Bank Palestinian Territory. Journal of Waste Management, 29: 2398-2403.

ALCO. (2011). Simplified Manual for Health Care Waste Management along the Abidjan-Lagos Corridor (pp. 10$33)$.

Al-Khatib, I.A., Khatib, RA. (2008). Assessment of medical waste management in Palestinian hospital. Eastern Mediterranean Health Journal, 12(3-4), 359-371.

Ananth, A.P., Prashanthini, C. and Visvanthan, C. (2010). Healthcare waste management in Asia. Journal of Waste Management 30: 145-161. 
Artiola, F.J. (2010). Clinical waste management in Malaysia: A case study at Teluk Intan Hospital. Canada, Prentice Hall. Pages 78-84

Bdour A, Altrabsheh, B., Hadadin, N., and Al-Shareif, M. (2006) Guideline for the Safe Management of Medical, Chemical, and Pharmaceutical Waste. National Institute for Environmental Training, Riyadh, Saudi Arabia.

Bdour, A., Altrabsheh, B., Hadadin, N. And Al-Shareif, M. (2007). Assessment of medical waste management practice: A case study of northern part of Jordan. Journal of Waste Management, 27: 746-759.

Birpinar, M.E., Bilgili, M.S. and Erdogan, T. (2009). Medical waste management in Turkey: A case study of Istanbul. Journal of Waste Management, 29: 445-448.

Blenkharn J. I. (2008), Standards of clinical waste management in hospitals - Second look, Journal of Hospital Infection 121, pp. 540-545.

Blenkharn, J.I. (2011). Clinical waste management. London: Blenkharn Environmental Ealing. Pages 281-292

Cheng, Y.W., Sung, F.C., Yang, Y.C., Lo, Y.H., Chung, Y.T. and Li, K.C. (2009). Medical waste production at hospitals and associated factors. Journal of Waste Management, 29: 440-444.

Clarke, J. (2008). Clinical waste in developing countries. Journal of Nepal Health Research Council, 28(1): 4467.

Clover, P. (2009). Safe management of healthcare waste guide. London: Royal College of Nursing. Pages 84-91

Coker (2009). Medical waste management in Ibadan, Nigeria: Obstacles and Prospects. February 2009. Waste Management 29(2): 804-811.

Coker AO, Sikiru KA, Syidhar MKC, Sangodoyin AY (1999). Characterization and Management of solid hospital wastes. Proceedings of the 25th WEDC conference, Addis Ababa, Ethopia, pp. 331-334.

Crick, N. (2012). Waste management. Environment Watch Botswana, 16: 12-15.

Da Silva, C.E., Hoppe, A.E., Ravanello, M.M. and Mello, N. (2005). Medical waste management in the South of Brazil. Journal of Waste Management, 25: 600-605.

Dasimah, O., Siti, N.N. and Subramaniam, A.L.K. (2012). Clinical waste management in District hospital of Tumpat, Batu Pahat and Taiping. Procedia Social and Behavioral sciences, 68: 134-145.

Diana, M. B. (2002). Hospital pollution prevention strategies. Environmental Management Branch, pp.142-149.

Diaz, L.F., Eggrerth, L.L. and Savange, G.M. (2008). The characteristics of healthcare waste. Journal of Waste Management, 28(7): 1219-1226.

Diaz, L.F., Enkhtsetseg, Sh., Enkhjargal, G., Eggerth, L., 2005. Characterization Study of Healthcare Wastes Generated in Ulaanbaatar, Mongolia, Final Report. Ministry of Health of Mongolia and WHO.

Frost, E. and Sullivan, M. (2009). US Clinical Waste Management and Disposal Market: A concern in the World. Washington, Clofts Press, pp. 212-218

Ghana Health Service (2008). Healthcare Waste Management. Accra, Ghana.

Goddu, V.K. Duvvuri, K. and Bakki, V.K. (2007). A Critical analysis of Healthcare waste management in developed and developing countries. Case studies from India and England. Journal of Waste Management, 7(2): 134-141.

Government of Botswana (GoB) (2007). Performance audit report on clinical waste management at referral hospitals: Princess Marina, Nyangwabgwe and Lobatse Mental Hospital. (Report no.3) Gaborone, Government Printer.

Hem, C. (1999). Hospital Waste - An environmental hazard and its management. International Society of Environmental Botanists. Archives of Environmental News-Newsletter of ISEB India, 5(3): 68-74.

Holmes, J.R. (2009). Managing waste in developing countries. New York: Wiley.

Haossain MS, Santhanam A, Norulaini NAN and Omar AKN (2011). Clinical solid waste management practices and its impact on human health and environment: A review. Journal of Waste Management, 31: 754-766.

Hossain, M.S., Santhanam, A., Norulaini, N.A.N. and Omar, A.K.N. (2011). Clinical solid waste management practices and its impact on human health and environment: A review. Journal of Waste Management, 31: 754-766.

J. Green and V. Caracelli, "Toward a conceptual framework for mixed method," Educational Evolution and Policy Analysis, vol. 11, no. 3, pp. 255-274, 1989.View at: Publisher Site | Google Scholar

Insa, E., Zamorano, M. and Lopez, R. (2010). Critical review of medical waste legislation in Spain. Resources, Conservation and Recycling, 54: 1048-1059.

Jamu, S., Magashula, A. and Muller, N. (2009). The national situational analysis of healthcare waste management in Botswana. Assessment of systems and processes at facility level, Botswana

Jang YC, Lee C, Yoon OS and Kim H 2006: Medical waste management in Korea. Journal of Waste Management, $80,107-115$.

Jang, Y.C. (2011). Infectious/ Medical/ Hospital waste: General characteristics in South Korea. Earth System and Environmental Sciences, Encyclopedia of Environmental Health, 227-231.

Johannessen, L. M. (2000). Healthcare Waste Management Guidance Note. Anchor Team, The World Bank. http://info.worldbank.org/etool/docs/library/128809/johannessen\%2019999pdf 
Kagonji, I.S. and Manyela, S.V. (2011). Analysis of measured medical waste generation rate in Tanzania District hospitals using statistical methods. African Journal of Environmental Science, 5(10): 815-833.

Kgosiesele, E. and Zhaohui, L. (2010). An evaluation of waste management in Botswana. Achievements and challenges. Journal of American Science, 6(9): 144-150.

Kumari, R., Srivastava, K., Wakhlu, A. and Sighn, A. (2012). Establishing biomedical waste management system in Medical University of India: A successful practical approach. Clinical Epidemiology and Global Health, 25(2):75-81

Kwawukume EY, Srofenyoh EK (2005). Screening for Premalignant Lesions of the Female Genital Tract. In Comprehensive Gynaecology in the Tropics. 1st edition Ashante and Hittshcer Press Danosoman, pp. 401402.

Lee, K.B., Ellenbecker, M.J. and Eraso, R.M. (2002). Analysis of recycling potential of medical plastic waste. Journal of Waste Management, 22: 461-470.

Mato, R.R.M.A. and Kassenga, G.R. (1997). A study on problems of management of medical solid waste in Dares Salaam and their remedial measures. Resource, Conservation and Recycling, 21: 1-16.

Mbongwe, B., Mmereki, B.T. and Magashula, A. (2008). Healthcare waste management: Current practices in selected facilities in Botswana. Journal of Waste Management, 28(1): 226-233.

Mbuyi, B. (2010). African cities in crisis: Managing rapid urban growth. Washington: Routledge, pp.8-12.

Ministry of Health (2006). MOH Policy and Guidelines for Health Institutions, Accra, Ghana.

Mmereki, B. (2009). Situational analysis report, extent and magnitude of incinerator induced pollution in Botswana. Gaborone, Botswana.

Mochungong, P.I.K. (2010). The plight of clinical waste pickers: Evidence from North West region Cameroon. Journal of Occupational Health, 52: 142-145.

Mohee, R. (2005). Medical waste characterization in healthcare institution in Mauritius. Journal of Waste Management, 25(6): 575-581.

Mokuolo, O. (2009). Improving the management of solid hospital waste in Nigerian hospitals. Health General Community. 25: 1-6.

Moritz, J.M. (1995). Current legislation governing clinical waste disposal. Journal of Hospital Infection, 30: 521530.

Mujeeb SA,Adil MM,Altef A, Hutin Y Luby S. (2003) Recycyling of injection equipment in Pakistan. Infect Control Hospital Epidemiol, 24:145-146.

Narayana, T. (2009). Municipal solid waste management in India: From waste disposal to recovery resources. Journal of Waste Management, 29: 1163-1166.

Nemathaga, F., Maringa, S. and Chimuka, W. (2008). Hospital solid waste management practices in Limpopo province South Africa: A case study of two hospitals. Journal of Waste Management, 28: 1236-1245.

Olatoye, O.B. (2009). Comparative analysis of healthcare waste management practices in two general hospitals in Nigeria. Institute of Charted Chemist of Nigeria, Nigeria.

Oweis, R., Al-Widyan, M., Al-Limoon, O., (2005). Medical waste management in Jordan. A study at the King Hussein Medical Center.

Patwary, M.A., O-Hare, W.T., Street, G., Elahi, K.M., Hossain, S.S. and Sarke, M.H. (2009). Country report: Quantitative assessment of medical waste generation in the capital city of Bangladesh. Journal of Waste Management, 29: 2392-2397.

Phengxay, S., Okumura, J., Miyoshi, M., Sakisaka, K., Kuroiwa, C and Phengxay, M. (2005). Health-care waste management in Lao PDR: a case study. Waste Management Research, 23; 571-581.

Prüss, A., and Townend, W. K. (1998). Teacher's Guide- Management of wastes from health-care activities, World Health Organization, Geneva, 227 pages.

Pruss, A., Giroult, E. and Rushbrook, P. (1999). Safe management of waste from health activities. Geneva, World Health Organization.

Ramokate, T. (2007). Knowledge and practices of doctors and nurses about management of healthcare waste at Johannesburg hospital in the Gauteng province, South Africa. MSc Degree Thesis. University of Witwatersrand, Department of Health Sciences.

Rappe, C.M. and Nyregen, G. (2009). Clinical Waste Management and Disposal markets: Huge impact on alternate site due to strangest regulations. Journal of Environmental Science and Technology, 21(5): 961-979.

Roe Gillis (2012), the Training Requirements for Medical Waste Handlers. Website: www.watse.al /training/requirements/medical/waste/handers

Samarakoon, M.A.S.C. And Gunawardena, N.S. (2011). An evaluation of healthcare waste management in hospitals of Colombo District. Journal of the College of Community Physicians of Sri Lanka, 16(2): 15-20.

Shaner, H., McRae, G., 2002. Eleven Recommendations for Improving Health Care

Waste Management, revised ed. CGH Environment Strategies, Inc., USA.

Sharma, B.K. (2007). Current status of healthcare waste management and proposed policy and guidelines for 
Maldives. Draft report, July 9-August 6. Meldives mission, WHO, 2015.

Sim, S. (2009). Health care waste disposal in municipal incinerators. Journal of Waste Management, 26(4): 44-47.

Singh, Z., Bhalwar, R., Jayaram, J. and Tilk, V.W. (2001). An introduction to essentials of Biomedical Waste Management. Medical Journal Armed Force India, 57(2): 144-147.

Taghipour, H., Mosaferi, M. (2009). Characterization of medical waste from hospitals in Tabriz, Iran. Science of the Total Environment, 407:1527-1535.

UNEP (1996). International source book on Environmental sound Technology for municipal solid waste management. UNEP, Technical publication.

UNEP (2002). Technical guidelines on the environmentally sound management of Biomedical and healthcare waste. Basel Convention, United Nation Environment Programme.

Verma, L. K. (2010). Managing hospital wastes. How difficult? Journal of Indian Society of hospital waste management, 9(1): 47-50.

Visvanathan, C. (1996). Hazardous waste disposal. Resources, Conservation and Recycling. 16: 201-212.

Visvanathan, C. and Prashanthini, V. (2009). Healthcare waste management in Asia. Journal of Waste Management, 30(3): 154-161.

Vorapong, M. (2009). Awareness and management of hospital waste in developing countries: A case study in Thailand, pages $1-75$.

Waldner, M. (2011). Medical waste disposal a mess. http://www.citypress.co.za/southafrica/news

Weir, E. (2002). Hospital and the environment. Journal of Canadian Medical Association, 166(13): 354-369.

WHO. (2015). Segregation, storage and transport of health-care waste. In: Chartier, Y. et al. (eds.), Safe management of waste from health-care activities (2nd ed.) Geneva, Switzerland: WHO Press, World Health Organization, pp. 77-104.

World Health Organisation, WHO (1999). Safe Management of Waste from Healthcare Activities, World Health Organisation report. World Health Organization (2005h). Safe Healthcare Waste Management (HCWM): Policy paper. Website: http://www.who.org/2015.

World Health Organisation, WHO (2004). Healthcare Waste Management policy paper. World Health Organisation, WHO. (2005). Management of Solid Health-Care Waste at Primary Health-Care Centres: A Decision-Making Guide. Geneva, Switzerland: WHO Press, World Health Organization.

World Health Organization (2008) - WHO healthcare waste categories,. Website: file:/E:Documents/WHO WASTE categories.html.

World Health Organization (WHO, 1999). Safety of injections. WHO-UNICEF-UNFPA joint statement on the use of auto-disable syringes in immunization services. Geneva: WHO Department of Vaccines and Biological, (WHO/V\&B/1999.25)

World Health Organization WHO (2010). A handbook of medical waste management guideline. Geneva, Appleton.

World Health Organization, Geneva. (1992). Managing medical wastes in developing countries: report of a Consultation on Medical Wastes Management in Developing Countries, Geneva, Available at: http://whqlibdoc.who.int/hq/1994/

World Health Organization, Geneva. (1992). Managing medical wastes in developing countries: report of a Consultation on Medical Wastes Management in Developing Countries, Geneva, and Available at: http://whqlibdoc.who.int/hq/2015. 